\title{
Synthesizing the Malthusian and Senian approaches on scarcity: a realist account
}

\author{
Adel Daoud $\star$
}

Food entitlement decline (FED) and food availability decline (FAD) are two approaches to explaining famines that have different policy implications. One focuses on the systemic level, whereas the other is concerned with the individual level. They therefore analyse relatively distinct causal mechanisms. Thus, an important question is whether these approaches can be reconciled. Another related question is how FAD- and FED-based explanations relate to classical Malthusian views about rapid food requirement increase (FRI). This paper analyses these questions and argues that these three approaches can indeed be reconciled within a single framework by outlining the causal sources of FAD, FED and FRI. This task requires, among other things, the separation of ontological categories and empirical measures. As a consequence of this argument, the paper suggests that there are only seven possible ontological combinations of how a famine situation can arise as a direct cause. Simultaneously, it maintains that there are virtually an infinite number of ways in which these combinations may act as indirect causes (rooted in economic, political and social conditions). The analysis is exemplified by the Bengal famine of 1943 because that famine is a well-known case. The wider research and policy applicability of this general account are discussed but have yet to be tested in relation to other scarcity cases (water, land, fish). This synthesis is made possible by the incorporation of critical realist interventions into economic theory.

Key words: Entitlements, Famine, Methodology, Scarcity, Realism

Frequently used acronyms: FAD, Food Availability Decline; FED, Food Entitlement Decline; FRI, Food Requirement Increase; HASAS, Holistic model of Absolute Scarcity, Abundance and Sufficiency; R-E-A, Requirements, Entitlements and Available quantities

\section{Introduction}

Various causal factors can generate famine and food insecurity (Shaw, 2007). The two most-recognized factors are food entitlement decline (FED) and food availability decline (FAD). These two factors represent different approaches to explaining famines. One focuses on the systemic level, whereas the other is concerned with the individual level. They therefore analyse relatively distinct causal mechanisms. An important question is thus whether these approaches can be reconciled. Some scholars have

Manuscript received 5 February 2015; final version received 21 August 2016.

Address for correspondence: Adel Daoud, Centre for Business Research, Cambridge Judge Business School, University of Cambridge, Trumpington Street, Cambridge CB2 1AG, United Kingdom; email: ad836@ cam.ac.uk

* University of Cambridge and University of Gothenberg

(C) The Author(s) 2017. Published by Oxford University Press on behalf of the Cambridge Political Economy Society. All rights reserved. 


\section{A. Daoud}

argued that the FAD and FED frameworks are generally incompatible perspectives (cf. Sen, 1981). In numerous studies, debates have raged between FAD and FED sympathizers. See, for example, the Niger famine of 2005 (Rubin, 2009), the Ethiopian Wollo famine of 1972-74 (Devereux, 1988), the Soviet famines of 1931-32 (Wheatcroft, 2007) and 1947 (Ellman, 2000) and the Chinese famine of 1959-61 (Kula, 1989). Such debates can also be found in more recent theoretical work (Qudrat-I Elahi, 2006; Alemu, 2007; Ó Gráda, 2008; Tauger, 2009). This paper will argue that the two factors can indeed be reconciled and will provide a framework for how this can be achieved.

Another closely related question, which has been somewhat under-emphasized, concerns how FAD and FED explanations relate to the classical Malthusian view, according to which famines do not necessarily arise out of food availability decline and certainly not out of entitlement decline (Lee and Feng, 1999; Wrigley, 1999), but out of rapid food requirement increase (FRI). There are some overlaps between the FAD and FRI approaches, most notably in terms of empirical measurements such as 'per capita food availability', but it seems that they involve relatively distinct underlying ontological causal factors (Alamgir, 1980: Rangasami, 1985). The former focus is on food production (supply side factors); the latter focus is on population and demographic trends (demand side factors). Accordingly, one of the most basic questions about famine causation concerns how the FAD, FED and FRI factors are related. I intend to explore these questions in this paper.

I will use an actual case as an empirical example to analyse the above questions concerning FAD, FRI and FED. To make the analysis more concrete, I will focus on the Bengal famine of 1943. It might seem odd to revisit such an old case, but I believe that the Bengal famine is a particularly good case for three reasons. First, the basic causes of the case have been heavily disputed compared to those of other famines (Famine Inquiry Commission, 1945; Sen, 1977; Sen, 1981; Greenough, 1982; Allen, 1983; Basu, 1984; Allen, 1986; Bowbrick, 1986; Sen, 1986; Bowbrick, 1987; Sen, 1987; Bose, 1990; Goswami, 1990; Sen, 1993), and they remain a matter of dispute (Tauger, 2003; Islam, 2007; Tauger, 2009). Second, the Bengal 1943 case has primarily been a matter of dispute between FAD and FED researchers, which makes the Bengal famine suitable given the purpose of this paper. Thus, analysing whether this dispute can be transcended constitutes a sufficient challenge. Third, as will be demonstrated, the Bengal famine highlights the significance of FRI ontological factors, and the importance of these factors has not been sufficiently emphasized in the FAD and FED approaches. Both camps assume that the FRI factors do not spring from a distinct causal source. By outlining the ontological presumptions of how scarcity is produced in famine events, this paper will show that this assumption is erroneous.

The paper begins by emphasizing the importance of the analytical difference between an approach and a hypothesis. This will decrease some of the confusion surrounding the debate between FAD and FED. Next, I will outline the ontological underpinnings of a state of starvation. I argue that when starvation is understood as a case of scarcity - stemming from either a lack of entitlement to sufficient amounts of food or a systemic lack of food - we can begin to disentangle the underlying causes. I briefly discuss the basic components of a general model of scarcity that can facilitate our understanding of the relationship among FAD, FED and FRI. Thereafter, this model will be applied to the Bengal case to demonstrate the concrete relevance of our analysis. The paper concludes with a discussion of the wider implications of the study, along with suggestions for further research and some policy recommendations. 
Judging by the Cambridge fournal of Economics, the field of critical realism in economics ${ }^{1}$ has primarily focused on issues of pluralism (Kaul, 2002; Lawson, 2006; Davis, 2008), neo-Marxist political economy (Nielsen, 2002), post-Keynesian economics (Downward, 2000; Lee, 2002), developmental economics (Dow and Dow, 2005), evolutionary economics (Castellacci, 2006), methodology (Downward et al., 2002), abstraction (Brown et al., 2002), equilibrium (Fleetwood, 1996) and critiques and counter-critiques (Baert, 1996; Peter, 2001; da Graca Moura and Martins, 2008; Peacock, 2008); ${ }^{2}$ however, it seems that no studies have focused on themes of scarcity, abundance and sufficiency in the context of famines. My intention is to contribute to the field from this perspective.

\section{Linking FAD, FED and FRI through a general framework for scarcity events}

I will advance two propositions in this section. First, I will argue that Osmani's account of the distinction between an approach and a hypothesis is an important starting point in reconciling the FAD and FED views (Osmani, 1995). Second, I will argue that Daoud's account of a general framework of scarcity events, which is referred to as the 'holistic model of absolute scarcity, abundance and sufficiency' (HASAS), provides an adequate basis from which to consider how this reconciliation could be further ontologically grounded (Daoud, 2007). This framework is based on a realist perspective, which is elaborated in the next section.

Osmani differentiates between the entitlement or FED approach versus the FAD approach, on the one hand, and the FED hypothesis versus the FAD hypothesis, on the other hand. The FED hypothesis proposes that 'modern famines are caused not so much by reduced availability of food as by adverse changes in the entitlement mapping of the poor' (Osmani, 1995, p. 260). This means that some famine cases are caused by FED and others are caused by FAD. This hypothesis interpretation implies that a famine can be explained either by FAD or by FED, but not by both.

Consequently, the FAD approach makes more far-reaching claims than the FAD hypothesis. Osmani writes,

The most persistent misunderstanding has been the notion that the essence of entitlement theory was to debunk the traditional 'food-availability-decline' (FAD) hypothesis of famine, and to replace it by the alternative hypothesis of entitlement failure. It is this hypothesis-view-i.e., the notion that the objective was to substitute one hypothesis of famine causation for another-that is responsible for a good deal of confusion and a lot of unwarranted criticism. In fact, what Sen was trying to substitute was not one hypothesis for another, but one approach for another. (Osmani, 1995, p. 289)

Accordingly, and most importantly, the FED approach does not discredit the usefulness of the FAD hypothesis. Instead, it attacks the reductionist claim of the FAD approach. More precisely, in the FED approach, entitlement failure becomes the definitional centre of a famine. Consequently, it does not reveal much about causation. Rather, it becomes the starting point of a research investigation. In this interpretation, according to Osmani, the entitlement approach is superior, at least conceptually, to the

${ }^{1}$ For a comparison of the main exponents of realism in economics, see Hodge (2008); see also Fleetwood (1999).

2 See also the special issue on critical realism (Blankenburg et al., 2002) for further studies. 


\section{A. Daoud}

FAD approach. One of the reasons for this, which Osmani refers to as the 'asymmetry of impact', is that even if supply failure is a central causal mechanism in a particular case, the FAD approach can only claim that food will not be sufficient on a systemic level and cannot specify why some groups of people are affected by starvation more than others. Thus, one central analytical conclusion of Osmani's argument is the following: an individual's entitlements are the mediating link between that individual and the available resources in the system in which he or she is embedded (Drèze and Sen, 1989; Osmani, 1995; Devereux, 2007; cf. Poulton et al., 2006; Shaw, 2007).

Although I build on Osmani's account, I also argue that his account needs to be complemented on at least two points. First, it is unclear how the FED approach can ontologically integrate the FAD hypothesis (the concept of ontology is defined in the next section). Second, the entitlement approach is committed to methodological individualism, which to a certain degree limits the possible causal influence that can be derived from social structures (De Waal, 2005; Jackson, 2005). The HASAS model can provide some answers, especially on the first point: for that, we need to examine the ontological assumptions of how starvation is made possible.

\subsection{The ontological underpinning of starvation}

What is the ontology of starvation? What ontological presuppositions need to be fulfilled to establish a situation in which people cannot feed themselves? By ontology, building on the critical realist point of view, most notably that of Lawson $(1997,2012)$ and Martins (2006), I refer to an enquiry into the nature of being. Social ontology is concerned with social issues and can be seen as a subset of this general ontology (Lawson, 1997). Social ontology can be seen as a causal map of certain social phenomena that may guide a researcher's scientific investigation. The better the map, the more precise the results of the investigation.

As Martins (2006, 2007, 2013) demonstrates, Sen's work on the capability approach should be primarily understood as an ontological under-labouring of social and economic theory. It should not be conceived as a specific theory of capabilities. Sen's ontology serves as a way to elaborate on categories such as capability, functioning and well-being. This social ontology should then be situated in a wider, geo-historically specific context when it is deployed and defined. These capabilities and functionings are by no means the same today as they have been at other times and in other places, and thus they must be understood relationally (Smith and Seward, 2009).

In this spirit, Daoud (2007, 2010, 2011a, 2011b) has argued that the ontology of starvation should be understood as an event of scarcity-in either individual or structural causes. The ontology of scarcity, in turn, is defined by the HASAS model, which is employed in Daoud's 2007 publication. The aim of this model is to provide a framework for studying the relationship between different stratifications of reality with regard to events of scarcity, abundance, and sufficiency. The model specifies the possible underlying causes of these events, that is, the causal influences of political, economic, social and environmental structures. One of the advantages of this model is that it orders the chain of causality in strata. It frames them multi-causally. Scarcity may arise as a consequence of various deeper or underlying causal factors (Shaw, 2007). The abundance or sufficiency of food may exist on a systemic level, but scarcity may continue to exist at the individual level (Sen, 1981). This is the definition of quasiscarcity (Daoud, 2007, 2010). Systemic scarcity may have partly natural causal sources 
(drought, cyclone), partly socio-cultural (institutional) causal sources-it might even be socially (politically) induced, artificially created, serving the ideological interests of given groups (Devereux, 2007; Howe, 2007). Even if the possible causes are many, the HASAS model specifies the chain of causality in a specific manner.

The basic components of HASAS are outlined in Figure 1: Figure 3, which is presented at the end of the paper, is an application of Figure 1; it is an ontological map of the Bengal famine. This causal model consists of three analytical or ontological layers. The first layer is called the actual level; different events of interest occur in this layer, including scarcity, abundance and sufficiency, along with their quasi-versions. This layer is explained by, conditioned by, or, analytically speaking, defined by the second underlying layer.

The second layer is the generative layer. An event of scarcity (abundance or sufficiency, along with their quasi-versions) is thus explained by three causal sources or necessary generative mechanisms. They are 'necessary' because they define scarcity. The first mechanism is human requirements $(\mathrm{R})$, which is the quantification of any type of human want or need in a given system (medicine, land, energy, water). In the present case, food needs are the main interest. These requirements are satisfied by various resources, which are referred to as available quantities (A). These two analytical categories define scarcity, abundance and sufficiency on a systemic level. In other words, human requirements and available quantities represent the aggregation of individual needs and goods.

The third mechanism or causal source, entitlements (E), mediates between a person (his or her needs) and the system that they are embedded in (Osmani, 1995). This is a necessary mechanism that determines whose needs will not be met in the event of scarcity. Entitlements should be understood in a general sense (Gasper, 1993), including both the informal and the politically defined transfer of resources (Drèze and Sen, 1989, p. 10; Devereux, 2007).

The third layer of the HASAS model refers to the deeper underlying factors that condition the second layer. The third layer is much more complex than the second.

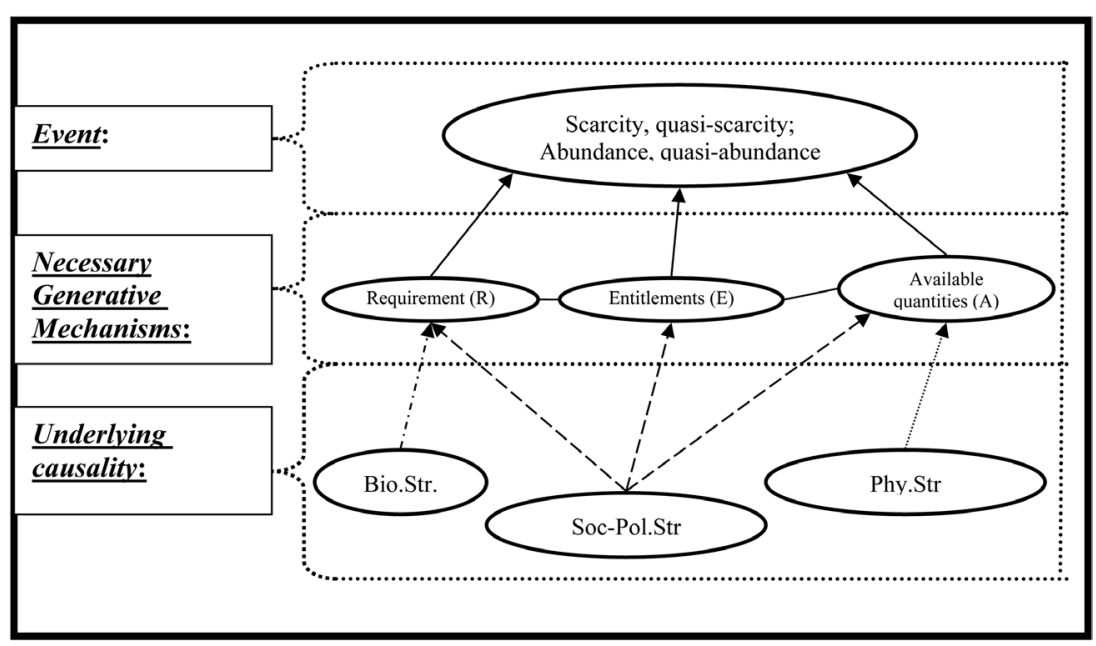

Figure 1. The Holistic Model of Absolute Scarcity, Abundance and Sufficiency Notes: Bio.Str = Biological strata; Soc-Pol.Str = Socio-political strata; Phy. Str $=$ Physical strata 


\section{A. Daoud}

It is the 'black box' of any given scarcity case. This layer focuses on structures and mechanisms that generate a specific constellation of R-E-A. For each necessary mechanism (with regard to $\mathrm{R}, \mathrm{E}$ or $\mathrm{A}$ ), there is a set of underlying causes. The mechanism of human requirements $(\mathrm{R})$ is, for example, conditioned by population growth rates, mortality rates and reproduction (family) norms; the mechanism of available quantities (A) is, for example, conditioned by arable land, climate and technology; and the mechanism of entitlements (E) is, for example, conditioned by various socio-cultural factors such as class, jurisprudence and social norms. As a result, these three necessary mechanisms are conditioned by underlying factors that are found on different ontological strata. Consequently, the most demanding investigative efforts lie here.

As the researcher begins to fill in the details in Figure 1 - as will be done with the help of Figure 3 below-the researcher proceeds from a higher level of abstraction to a lower level of abstraction. This transition is equivalent to the transition from a philosophical ontology to a scientific ontology: from the general to the specific (Martins, 2006, pp. 675-76). In our case, Figure 1 represents the ontology of scarcity (abundance and sufficiency) and, with its transition to Figure 3, a specific scientific ontology of starvation and in the context of the Bengal famine.

Moreover, it may now be clear that as argued by Osmani, various hypotheses can be proposed regarding the causality that underlies the R-E-A relationship. FAD and FED correspond neatly with the E-mechanism and the A-mechanism, respectively. Moreover, as the HASAS model reveals, there is a third causal source, namely, the $\mathrm{R}$ mechanism, which alone can cause systemic scarcity (FRI). However, one issue is not apparent from the debate on the causation of the Bengal famine, but it is revealed to be relevant through the lens of the HASAS model. Building on this line of thought, the HASAS model provides an explicit account of the causal links among various causal sources.

\section{The 1943 Bengal famine: an example}

World War II raged for almost four years, conditioning the British interest in South Asia (Mansergh and Lumby, 1973). By the end of 1941, however, the war had taken a critical turn. Japan and India were officially at war on 8 December of that year. The first air raids on the Burmese city of Rangoon occurred on 23 January 1942. On 15 February 1942, Singapore came under Japanese control, and Rangoon was occupied at the beginning of March. At that time, the governments of India and Bengal implemented the 'denial policy'. There was a surplus of rice; restrictions were placed on boats and other facilities and infrastructures were either purchased by the government or destroyed by the Indian military to prevent a potential invading army from benefitting from those resources (Bhatia, 1967, p. 326).

FAD advocates regard these events as important, but merely contributing factors to the famine. A series of natural disasters that occurred at the end of 1942 should be seen as the major cause of the famine (Bowbrick, 1986, 1987). The Famine Inquiry Commission wrote that 'On the morning of 16 October 1942, a cyclone of great intensity accompanied by torrential rains, followed later in the day by three tidal waves, struck the western districts of the province... the standing aman crop, which was then flowering, was in large measure damaged' (Famine Inquiry Commission, 1945, p. 32). After these events, a fungus disease caused further damage (Padmanahan, 1973; cf. Tauger, 2003). At this point, according to the Commission, even if these natural events 
were the primary causes of the famine, this, 'however, was not necessarily in itself an unmanageable problem' (Famine Inquiry Commission, 1945, p. 35). It was not only that the yield of the rice crop was short but also that the carryover $(\mathrm{Cr})$ was smaller than normal. This shortage created further pressure on an already-pressured food distribution system. Thus, these facts are regarded as central to the FAD approach (Bowbrick, 1986, 1987).

Whether these causes were sufficient to cause the famine, they seem to have been the main reasons for traders and consumers to begin expecting that the next year's food supplies would be lower than normal, providing an incentive for hoarding and speculation. Shortly after these disasters occurred, prices began to rise (Famine Inquiry Commission, 1945, p. 33).

In December 1942, the price for one maund ${ }^{3}$ of rice had doubled compared to January of the same year. In spring 1943, prices had almost tripled compared to January 1942. By the time the first serious signs of famine occurred, at the beginning of that summer, prices had quadrupled. It was reported that in some places prices had increased 6-fold (Famine Inquiry Commission, 1945, pp. 40, 216; Sen, 1981, p. 61; Goswami, 1990, p. 448). This severe price inflation was further aggravated by ineffectively coordinated government actions.

When the government of Bengal finally recognized the gravity of the situation, various actions were taken. The first and second procurement schemes were initiated not only to secure food supplies to Calcutta but also to break the spiral of speculation on food prices. On 22 December 1942, controlled prices were introduced and the export of Bengal rice was prohibited. The aim was 'to break the Calcutta market' (Famine Inquiry Commission, 1945, pp. 36-37). Further policies were pursued that ultimately determined who would be affected by starvation, leading to famine. The main political priority was to secure food supplies for industrial labour (letter from the Government of Bengal to the Chamber in Famine Inquiry Commission, 1945, p. 30).

The government's actions lasted from December 1942 to March 1943. After March 1943, free purchase at market prices resumed because the government's policies had been effective, partially because of corruption (Basu, 1984), which caused additional inflationary pressure (Sen, 1981, p. 56). These measures, which started by controlling the market and then suddenly decontrolled it, seem to have played a significant role in causing the famine. The situation was adversely reinforced by both administrative chaos and the needs of the war economy (what Sen calls a 'boom famine'), which was conditioned by the colonial relationship with London (Bose, 1990, p. 717). Basu adds that both religion and colonialism played a major role in this scenario (Basu, 1986, p. 602). Judging from the journal of the Viceroy, Lord Wavell, who came to power during the final stage of the famine, the British government was not interested in helping (Denied aid, $\mathrm{Dad}$ ) a relatively insignificant colony, especially in the context of World War II (see the letters dated 25 October 1944 from the Viceroy to Winston Churchill; Moon, 1973, pp. 94-95; see also Mukerjee, 2010).

All of the relevant events are summarized in Figure 2. This figure plots the two main factors: the upper part shows three important indices (food price, food supply and excess death rates; the comparison year is 1941 for all three of the indices), whereas the lower part depicts the relevant events that could have contributed to the Bengal famine. The timeline brings these two parts together and consequently

3 One maund is 37.4 kilograms. 


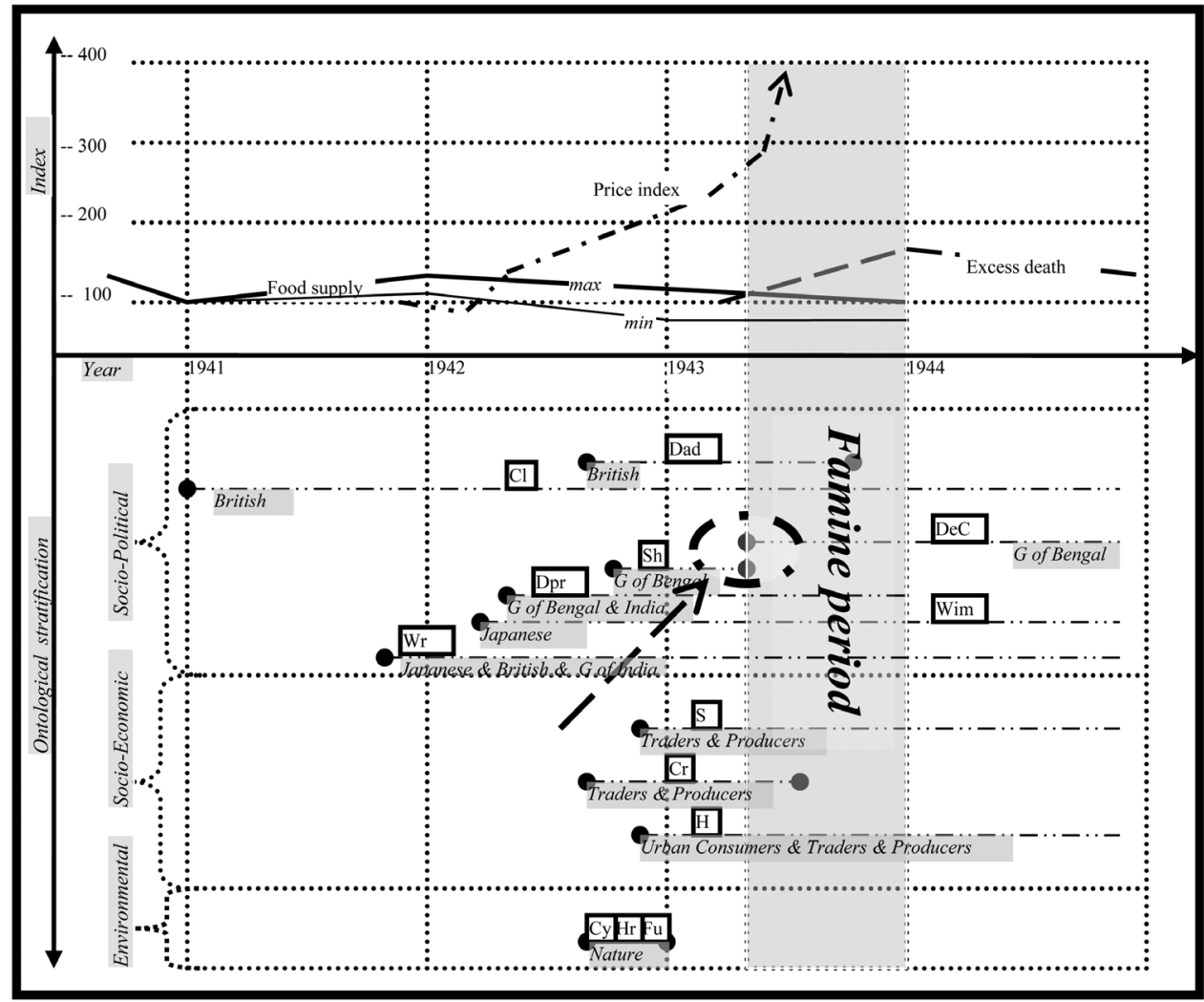

Figure 2. Diachronic Analysis of the Famine

Notes: $\mathrm{Cl}=$ Colonialism; $\mathrm{Cy}=$ Cyclone; $\mathrm{Cr}=$ Carryover; $\mathrm{Dad}=$ Denied aid; $\mathrm{DeC}=$ Decontrol; $\mathrm{Dpr}=$ Defence preparation; $\mathrm{Fu}=$ Fungus disease; $\mathrm{H}=$ Hoarding; $\mathrm{Hr}=$ Heavy rain; $\mathrm{S}=$ Speculation; $\mathrm{Sh}=$ Government schemes; Wim $=$ Cut or delayed wheat import; Wr=War

facilitates a diachronic analysis of the causes of the famine. In March 1943, the first serious signs of the famine began to emerge. According to Sen, the famine can be divided into three phases. The first phase lasts from the beginning of 1942 to March 1943. At this point, the famine had yet not begun. Nevertheless, there were signs of severe economic, political and social distress. Adding to the sharp rise in food prices, increased unemployment, wage decline and the fear of possible Japanese aggression created some of the fundamental conditions for the famine. In the second phase, from March 1943 to November 1943, deaths that were directly related to starvation reached a peak. In the third phase, from November 1943 through most of 1944, acute starvation had passed. Still, deaths that were related to famine epidemics (e.g. cholera, malaria, smallpox) reached a peak (cf. De Waal, 1990, 2005). This was largely caused by human immune system deficiency caused by malnutrition (Sen, 1981, pp. 55-56). There are various estimations of the number of excess deaths, ranging from 1.5 million (Famine Inquiry Commission, 1945, pp. 225-27) to as many as 3.5 to 3.8 million (Greenough, 1982; cf. Sen, 1981, p. 52). Tim Dyson and Arup Maharatna estimate the number of excess deaths to be approximately 2.1 
million, which falls in the middle of this range (cf. Dyson and Maharatna, 1991, p. 297; Bhrolcháin and Dyson, 2007).

As we can see in Figure 2, first, the government's decision to start by controlling the market (Sh) was nevertheless accompanied by defence preparation (Dpr), and the cut in wheat imports (Wim) overlapped with an ever-increasing rice price index in that time period; second, and more closely related to the basic causes of the famine, the government's decision to suddenly decontrol the market $(\mathrm{DeC})$ directly preceded the famine period, which is indicated by the grey area in Figure 2 (with excess death rates). Given the presented material, it appears that the government of Bengal had the main responsibility for providing its population with food and therefore was accountable for not effectively managing this crucial task.

Accordingly, human factors played a major role in the famine. The question is, however, could these human factors alone have produced a famine? What impact did the cyclone (Cy), heavy rain $(\mathrm{Hr})$ and fungus $(\mathrm{Fu})$ have on food availability? This brings us to the heart of the dispute: Was food actually scarce (FAD)?

\subsection{On the causal contribution of FAD}

Table 1 summarizes the food supply data presented in four different studies. These studies were chosen because they provide either original data or innovative re-interpretations of data. The base year is 1941. This is the comparison year because Sen assumes that 1941 's food supply was worse than in 1943, which is identified as the famine year.

Accordingly, in the Commission's view, there is 'no doubt that shortage of supplies was a basic cause of the famine' (Famine Inquiry Commission, 1945, p. 77); however, the estimation that was made by the Commission actually shows that there was 13\% more food in 1943 than in 1941 (rice estimations only). Sen, however, offers an adjustment of the Commission's figures. He concludes that there was not $13 \%$ more food, but somewhat less, $11 \%$ (rice and wheat estimations). Both Goswami (1990) and

Table 1. Comparison of different studies on the Bengal food supply

\begin{tabular}{lllll}
\hline Year & $\begin{array}{l}\text { the Commission } \\
(1945)^{\mathrm{a}} \\
\text { (only rice) }\end{array}$ & $\begin{array}{l}\text { Sen }(1981)^{\mathrm{b}} \\
\text { (rice }+ \\
\text { wheat) }\end{array}$ & $\begin{array}{l}\text { Goswami } \\
(1990)^{\mathrm{c}} \\
(\text { only rice) }\end{array}$ & $\begin{array}{l}\text { Islam } \\
(2007)^{\mathrm{d}} \\
\text { (rice }+ \\
\text { wheat) }\end{array}$ \\
\hline 1938 & 122 & 123 & 116 & 115 \\
1939 & 119 & 118 & 115 & 110 \\
1940 & 121 & 122 & 115 & 115 \\
1941 & $\mathbf{1 0 0}$ & $\mathbf{1 0 0}$ & $\mathbf{1 0 0}$ & $\mathbf{1 0 0}$ \\
1942 & 132 & 131 & 106 & $\mathbf{9 8}$ \\
$\mathbf{1 9 4 3}$ & $\mathbf{1 1 3}$ & $\mathbf{1 1 1}$ & $\mathbf{9 6 . 3}$ & -2 \\
Diff. of & +13 & +11 & -3.7 & \\
$(1943-1941)$ & & & &
\end{tabular}

Notes:
(a) See Appendix 2, pp. 202-17 in the Commission's report.
(b) See Sen (1981, p. 61).
(c) See Stock adjusted rice supply, calendar year (SUPR1), Goswami (1990, p. 455).
(d) See Islam (2007, pp. 428, 439). 


\section{A. Daoud}

Islam (2007) present slightly different data. Goswami argues that there was 3.7\% less food available in 1943 than in the comparison year (1941) (rice only). Nonetheless, Islam claims that this number was only $2 \%$ less (rice and wheat). Both Islam and (especially) Goswami emphasize that FAD is an important explanatory variable that is omitted by Sen. Although others concur with this critique, no one has presented any original data. Thus, the FAD hypothesis cannot simply be refuted.

Nonetheless, even if we use the estimation that indicates the most severe food supply decline and that mainly focuses on rice production, namely, Goswami's estimation, it is difficult to conclude that a dramatic FAD occurred. Indeed, food availability was lower compared to 1941, but only slightly. There were other years in which the decline had been more problematic but famine did not occur. Bhatia argued that the crop yield in 1928 was 'sufficient only for 45 weeks and in 1936, for 44 weeks. In both these years there was considerable distress but no abnormal rise in prices and, consequently, no deaths from starvation' (Bhatia, 1967, p 318). Indeed, the Commission estimated that food production in 1943 should have been sufficient for 43 weeks (compared to only 39 weeks in 1941), including carry-over for approximately 49 weeks (Famine Inquiry Commission, 1945, pp. 13, 211). This is only three weeks short of weekly requirements (approximately 6\%). Nevertheless, it is difficult to be entirely conclusive about the food supply data. However, it does seem relatively clear that a situation of severe food scarcity (or systemic abundance of food) can be ruled out.

Accordingly, it seems plausible to claim that the food supply was sufficient (neither abundant nor scarce), what Bowbrick (1986) calls a 'first degree shortage', meaning that 'there is sufficient food to provide a barely adequate diet for everyone, provided that there is rationing' (p. 106). Indeed, this also seems to be the Commission's position (Famine Inquiry Commission, 1945, p. 77). This situation is what Ellman calls $\mathrm{FAD}_{2}$, meaning preventable FAD, in his analysis of the 1947 Soviet famine (Ellman, 2000 , p. 621). Hence, even if there was a decline in food availability, it was not particularly dramatic, and thus Goswami's findings cannot account for the huge catastrophe (Islam, 2007, p. 429). This reinforces the hypothesis that the Bengal famine was produced by a lack of efficient governmental intervention.

Indeed, an $\mathrm{FAD}_{2}$ situation is a plausible description of the Bengal famine, which was made possible by policy failure. However, was this situation further aggravated by a food requirement increase (FRI)? The HASAS model indicates that we should control for such a condition.

\subsection{On the causal contribution of FRI}

There seems to have been yet another central factor or condition that contributed to the Bengal famine that should be considered vis-à-vis the FAD and FED factors. Indeed, some researchers have argued that it is not FAD, but food requirement increase (FRI), i.e., the Malthusian principle of population (Malthus, 1826), that is the primary long-term factor in the generation of famine (Patnaik, 1991; Alemu, 2007). This argument involves rapid population growth that increases geometrically (FRI) while available food quantities (A) remain practically static (a mathematical increase). It is true that on a per capita basis, the two theories (FAD and FRI) obtain the same result, but they have very different underlying causal factors. Obviously, all things being equal, rapid population increase tends to generate more food insecurity, which makes people more vulnerable to an FAD. However, the point is that FRI 
alone may create a systemic scarcity situation without any FAD involvement (Alemu, 2007, p. 114). Bengal and modern Bangladesh seem to be more sensitive to this type of scenario (Robinson, 1974).

Indeed, increased food requirements in the Bengal system seem to have been an important contributing factor. There was a relatively rapid pan-Indian population increase, along with a population increase in Bengal $(\mathrm{Pp})$. The Bengal population increased from 37 million in 1881 to 61.5 million in 1941 (Greenough, 1982, p. 62; Islam, 2007). The Bengal province, which is one of the world's most fertile areas, 'is no longer an exporter of foodstuffs or even self-sufficient' (Greenough, 1982, p. 8), and indeed, 'a classical Malthusian situation of population outstripping productive resources developed' (Greenough, 1982, p. 62). Even during normal periods, food security in Bengal was generally low (Famine Inquiry Commission, 1945, pp. 6-7).

A pan-Indian estimation of average annual per capita food output from 1893 to 1946 shows a decline of $32 \%$. This is primarily attributable to a pan-Indian population increase of $38 \%$ (Bhatia, 1967, p. 315); however, there was an almost $61.4 \%$ increase in Bengal alone (see Table 2). A major population increase occurred from 1931 to 1941, which further pressured the Bengal food system. This strengthens the validity of treating FRI as an important background condition of the famine.

Nonetheless, $\mathrm{FAD}_{2}$ and FRI alone cannot explain the Bengal famine, because the food supply was sufficient on a systemic level. Both factors, especially FRI, provide us with some of the main causal background of the famine, but they cannot account for why the famine was distributed as it was. Herein lies one of the main explanatory powers of FED. Its main function is to provide an account of people's socioeconomic relationship to the food goods that are available in a given system, which determines who will starve and who will not (Osmani, 1995). Note that both FRI and FAD can only refer to the properties of the system (i.e., scarcity, abundance and sufficiency on a systemic level), whereas FED mainly focuses on those properties at the individual level (endowments). This is an important analytical distinction to bear in mind.

\subsection{On the causal mediation of FED}

With a focus on the distinction between the systemic and individual levels, we can outline the causal mediation of FED. Sen's main argument is that a considerable number of people were not required by the war economy (i.e., unemployment), and those

Table 2. Population growth in Bengal, 1881 to 1941 (millions) $^{4}$

\begin{tabular}{lllll}
\hline Year & Total & Urban & Rural & Net increase \\
\hline 1881 & 37.01 & 2.24 & 34.77 & - \\
1891 & 39.81 & 2.22 & 37.59 & 2.80 \\
1901 & 42.88 & 2.60 & 40.28 & 3.07 \\
1911 & 46.31 & 2.97 & 43.34 & 3.43 \\
1921 & 47.59 & 3.21 & 44.38 & 1.28 \\
1931 & 51.09 & 3.71 & 47.38 & 3.50 \\
1941 & 61.46 & - & - & 10.37 \\
\hline
\end{tabular}

Source: Greenough (1982, p. 62).

${ }^{4}$ Adopted from Greenough (1982). 


\section{A. Daoud}

who had a job did not receive a salary that matched the dramatic food price increase. This created severe food insecurity. Table 3 identifies certain key details. It shows the indices of the exchange rates between agriculture labour and foodstuffs. The data show that the exchange index (wage relative to the price of rice) from 1942 to 1943 was only 32 compared to the normal period from 1939 to 1940 , which was the worst period of the Bengal famine. This means that what an agriculture labourer could earn in the period from 1942 to 1943 was only $32 \%$ of what he or she could earn in 1939-40.

The urban population was much more food secure than the rural population, not only because they were needed by the war economy but also (and primarily) because they were prioritized by the government (Sen, 1981, pp. 75-78; Patnaik, 1991, pp. 5-6). The rural population was the most affected by the deprivation. The government's main priority was to secure the country's industry (Sh) and prepare for a possible Japanese invasion. This is, of course, related to the fact that India was a British colony $(\mathrm{Cl})$. It is arguable that the government's priorities would have been different if this condition had not been present (Mansergh and Lumby, 1973; Moon, 1973; Sen, 1981; LawSmith, 1989).

Thus, 'having' or 'not having' is a function of social entitlement, which is directly linked to one's socioeconomic position (family, clans, castes, gender). This condition results in unequal opportunities in accessing food. Even if Sen does acknowledge the relevance of social structures and power relations, these notions are not properly integrated into the entitlement approach (Fine, 1997, pp. 630-32; Jackson, 2005, pp. 120 21). However, the recent research has extended Sen's work to explicitly incorporate social structures and power relations (Martins, 2006, 2013; Smith and Seward, 2009; cf. Lawson, 2012). Martins (2006, p. 676), for example, shows that by elaborating on the ontological underpinnings of Sen's capability approach, there is a clarified understanding of social positioning, power relations and capabilities. Nonetheless, FED cannot adequately explain the underlying power relationship between the Bengal authorities, the central government and the ruling class, namely, the associates of the British Empire, 'which ultimately determines the "exchange entitlement"' (Basu, 1986, p. 598; cf. Mukerjee, 2010). Thus, the focus on underlying human action and

Table 3. Indices of exchange rates between agricultural labour and foodgrains in Bengal ${ }^{5}$

\begin{tabular}{llll}
\hline Year & Wage index & Foodgrains price index & Index of exchange rate \\
\hline $\begin{array}{l}1939-40 \\
(1940)\end{array}$ & 100 & 100 & 100 \\
$\begin{array}{l}1940-41 \\
(1941)\end{array}$ & 110 & 109 & 101 \\
$\begin{array}{l}1941-42 \\
(1942)\end{array}$ & 115 & 160 & 72 \\
$\begin{array}{l}1942-43 \\
(1943)\end{array}$ & 125 & 385 & 32 \\
$\begin{array}{l}\text { st } \text { half of } 1943-44 \\
(1943)\end{array}$ & 130 & 385 & 34 \\
\hline
\end{tabular}

Source: Sen (1981, p. 64).

5 Adopted from Sen (1981). 
interaction in relation to famines is one step towards introducing the relevance of power (Keen, 1994; Devereux, 2007; Shaw, 2007). In the next section, I will summarize how the main FAD, FED and FRI factors interacted, as framed by the HASAS model. I will specifically focus on some of the most important human actions underlying the Bengal famine.

\section{A synchronic analysis of FAD, FED and FRI in the Bengal case}

To summarize, framed by the HASAS model, which is divided into three analytical layers, the following picture emerges (see Figure 3). In the first layer, there was an event (the Bengal famine; a scarcity situation), which is, in turn, divided into two levels. On a systemic level, there was a general sufficiency of food in the Bengal system. On the individual level, however, the people who starved to death experienced a quasi-scarcity of foodstuffs, which means that there was enough food in Bengal, but some people were excluded from accessing it, and consequently, they starved to death. ${ }^{6}$

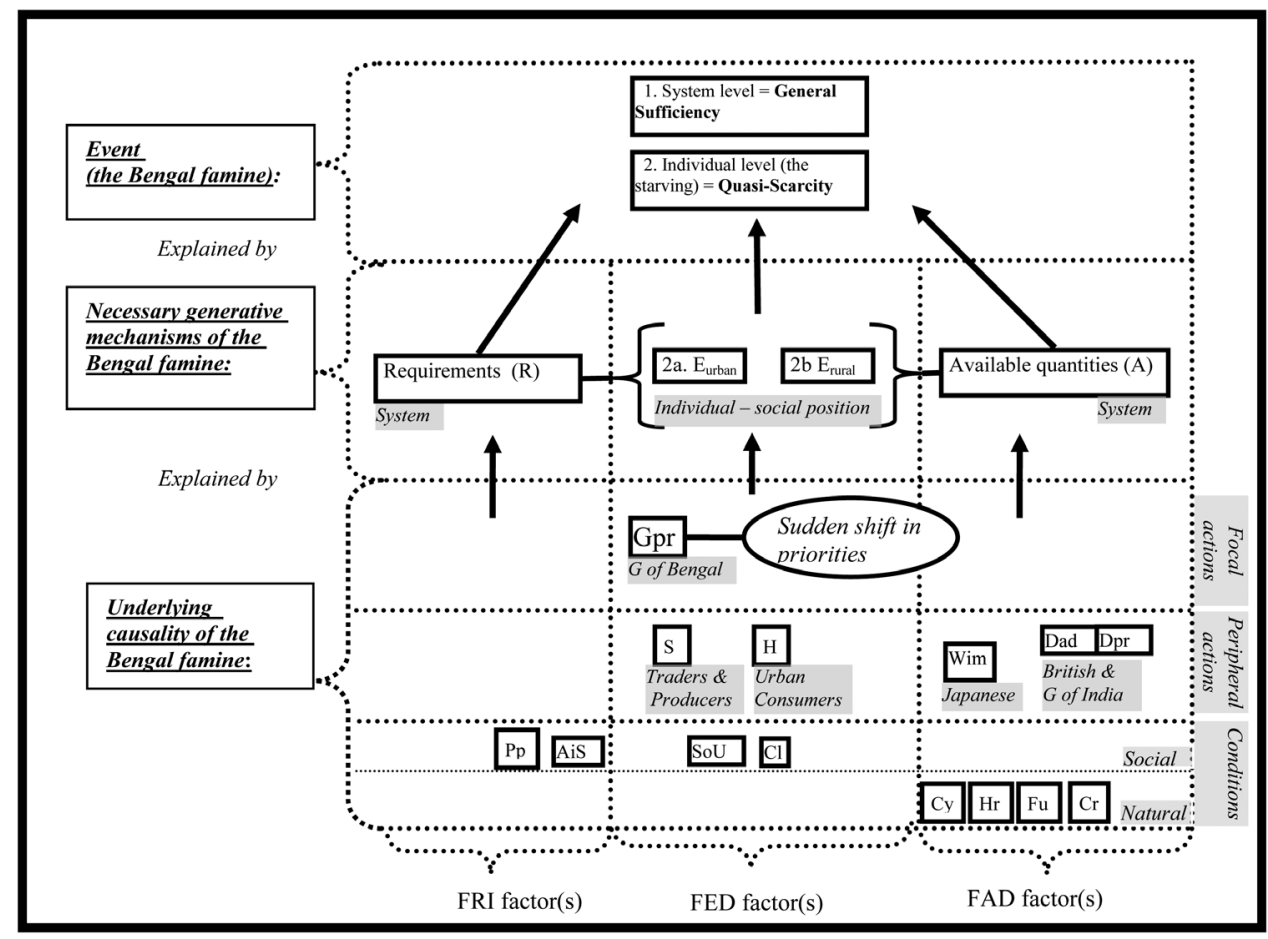

Figure 3. Synchronic Social and Cultural (Events in a Cross-SectionalView): Applying the Holistic Model of (Quasi) scarcity and (Quasi)abundance

Notes: $\mathrm{AiS}=$ All-India situation; $\mathrm{Cl}=$ Colonialism; $\mathrm{Cy}=\mathrm{Cyclone} ; \mathrm{Cr}=$ Carryover; $\mathrm{Dad}=$ Denied aid; Dpr $=$ Defence preparations; Gpr $=$ Government priorities; $\mathrm{E}_{\text {urban }}=$ Entitlements of the urban population; $\mathrm{E}_{\text {rural }}=$ Entitlements of the rural population; $\mathrm{Fu}=$ Fungus disease; $\mathrm{H}=$ Hoarding; $\mathrm{Hr}=$ Heavy rain; $\mathrm{Pp}=$ Population increase; $\mathrm{S}=$ Speculation; $\mathrm{SoU}=$ Social unrest; $\mathrm{Wim}=$ Cut or delayed wheat import

${ }^{6}$ Thus, the term 'quasi' refers to the fact that people did not have to starve because there was enough food. 
The second layer, which consists of three necessary mechanisms, directly explains the event in question. These mechanisms are requirements $(R)$, entitlements $(E)$ and available quantities (A). Scarcity can arise as a consequence of any of these failingshence, FRI, FED and FAD, as elaborated at the beginning of this paper. This second layer (R-E-A) defines systemic and individual scarcity, sufficiency and abundance of resources. The relationship between requirements and available quantities (R-A) defines the systemic level, whereas entitlements (E) relate the individual to the system. Given various individual social positions in society (based most notably on class, ethnicity and gender), people will have different entitlement sets. In the Bengal case, the most relevant social position or distinction is the one between the urban and the rural, because those who starved were primarily from the rural areas. Consequently, the worst-affected groups of people were, in descending order, fishermen, transport workers, paddy huskers, agricultural labourers, craftsmen and non-agricultural labourers (Sen, 1981, p. 70). This proposition is supported by the Commission (Famine Inquiry Commission, 1945, p. 5).

The character of this second layer (R-E-A) is explained by a number of underlying mechanisms. The central question in this case is as follows: How can we explain the fact that more people in rural than urban areas were affected by famine? Why is that the crucial question in the Bengal case?

To answer this question, we can divide this layer into focal actions, peripheral actions and general conditions (Archer, 1995, p. 160). Accordingly, actors and their actions are seen as one of the most important underlying mechanisms in this analysis (Keen, 1994; Macrae and Zwi, 1994; Devereux, 2007; Shaw, 2007). This is because even if FAD occurs, the question is how it can be effectively countervailed. It is primarily human actors who can bring about famine, either intentionally or as an unintended consequence. It is also only human action that can countervail certain famine threats that arise from human (conflict) or non-human forces (climate shocks) (Howe, 2007). Given the presented material on the Bengal famine, one of the central questions is as follows: 'How was the Bengal famine possible given that there was enough food?'

There are at least five central actors with the power to cause or prevent a famine in this case. The first actor was the Japanese army. Its main goal was to prevail against the British and thus against India. They wanted to undermine the British and possibly invade Bengal, and a famine might have served that purpose. They managed to cut wheat imports (Wim) to Bengal. The Japanese army carried out air raids on Calcutta, which forced the British to make extensive defence preparations (Dpr) (Famine Inquiry Commission, 1945, p. 37). Nevertheless, because there was enough food in the Bengal system, the actions of the Japanese cannot be seen as a focal point in explaining the famine: their actions were peripheral.

The second actor (or set of actors) was the traders and producers. Some researchers regard the actions of the traders and producers as responsible for huge price inflation and thus as the main cause of the famine, that is, market failure (Ravallion, 1987). This was achieved through extensive speculation $(\mathrm{S})$ and hoarding $(\mathrm{H})$ : urban consumers were also hoarding to secure their livelihood. It is true that the huge price inflation cannot be accounted for without acknowledging that there was a great deal of speculation going on, but those actions were not unusual. In a capitalist system, traders' default is always to maximize profit. They maximize in non-famine situations and famine situations alike. Thus, they were exercising the same type of causal pressure on the market as in a normal situation, in which, of course, no famines necessarily occur. 
The third actor was the British authorities. They did not aid (Dad) the Bengal people when it was needed. Their main interest was in countervailing the Japanese threat and maintaining control over India. One might argue that aiding Bengal would have given them some goodwill in a politically and socially unstable area. This is true, but because there was enough food in the Bengal system, their actions or inaction cannot be considered as focal in explaining the famine.

The same argument is valid for the Indian government, the fourth actor. They induced, as part of their defence preparations, a denial of trade among India's various provinces. However, given that there was enough food in the first place, this must also be considered a peripheral action. Of course, the Indian government did play an important role in the course of actions that would be taken by the fifth actor.

Thus, it seems that it is mainly the fifth actor, the Bengalese government, which unintentionally triggered the famine. Once that happened, it also had the primary responsibility and power to introduce effective famine relief, but it failed to do so. As shown in Figure 2, the transition point between controlling (Sh) and decontrolling (DeC) the food market marks the point at which excess death begins to rise. It is this sudden shift in priorities that should be seen as the focal action that explains the Bengal famine. As described earlier, the government's priorities were directly oriented towards maintaining food supplies to the industrial areas of Bengal, which then favoured the urban population and disfavoured the rural population.

This shift in priorities was heavily conditioned by the British colonial apparatus (Cl). Late actions to alleviate the distressed situation in 1943 were partly the result of this influence, a point argued by Bose (Bose, 1990, p. 717). Hence, the colonial relationship cannot be overlooked in the Bengal famine (cf. Marx, 1853). The Bengal government's priorities were influenced by India's central government, which in turn was shaped by the British Empire (Basu, 1986).

Moreover, the increase in the Bengal population ( $\mathrm{Pp}$ ) occurred primarily in the rural areas, which made this group even more vulnerable to food insecurity (FRI). This is a crucial causal background condition. The government prioritized the livelihood (food security) of the urban population over that of the rural population. Urban individuals' entitlement was thus enforced by two factors: the government (Sh) and the demand of the labour market. Indeed, as the famine inquiry commission wrote, 'an even more serious failure [FAD] had occurred only two years before in 1941, and had led to nothing more serious that a state of scarcity which was successfully alleviated by the usual relief measures' (1945, p. 35). Thus, even if the exchange entitlements of the rural population declined (market exchange), the government's inaction in securing other types of entitlements for the rural population must be seen as crucial in explaining why FED occurred: No transfer entitlements through viable policy or extended entitlements through informal channels were used.

Accordingly, although population increase $(\mathrm{Pp})$, colonialism $(\mathrm{Cl})$ and climate shocks ( $\mathrm{Cy}, \mathrm{Hr}, \mathrm{Fu}$ ) should be seen as important background conditions of the famine, it is mainly the government priorities that should be viewed as the focal explanation for why the famine occurred.

\section{Discussion-further research and policy recommendations}

In this paper, I have argued that competing accounts of a famine could be incorporated under a single ontological framework of the events of scarcity, abundance 


\section{A. Daoud}

and sufficiency (the HASAS model). This was achieved in three analytical steps. As a first step, we recalled the analytical distinction between an approach and a hypothesis. It was then argued that the FED approach is fully compatible with not only the FAD hypothesis but also the FRI hypothesis. This is indeed Sen's position: 'The links between food availability and entitlements are indeed numerous and often important' (Drèze and Sen, 1989, p. 26). As a second step, it was demonstrated that Osmani's account could be clarified and generalized further using the HASAS model, which views causality in a holistic way (Daoud, 2007; cf. Mallory et al., 1926; Shaw, 2007). This model offers an ontological or causal map of scarcity, abundance and sufficiency. As a third step, the paper applied the first and second steps to an actual case, namely, the Bengal famine, to test the applicability of this account. There are four implications that are worth emphasizing.

\subsection{There are many indirect causal sources, but only seven possible direct causes}

In theory, the HASAS model shows that there are three direct causal sources of any given famine or scarcity event. This model is defined by the R-E-A relationship, which in turn specifies seven main causal combinations: that is, different combinations of R-E-A. The following seven combinations are possible: (1) Solely R; (2) R\&E; (3) R\&E\&A; (4) R\&A; (5) solely E; (6) E\&A; and (7) solely A. ${ }^{7}$ As far as we know, defining the set of possible direct causes of famines in this way seems not to have been done before in the literature.

All else being equal, the available quantities (FAD) may dramatically fall, the population may grow at an exponential rate (FRI) or entitlements (FED) may fail because of socioeconomic exclusion - or a combination of these situations can exist. As a first step, the researcher needs to identify which of these seven combinations is the cause of the famine at hand. What are the direct causes? In some complex famine cases, such as the Bengal famine, elements of all three are likely to be active to different degrees (cf. Macrae and Zwi, 1994). As a second step, one must analyse what brings about that particular combination. What are the indirect or underlying indirect causes? This second step constitutes the 'black box' of any given scarcity (famine) case. This means that even if we only have seven possible direct causes, there are many possible indirect causes for any famine that are rooted in economic, social, cultural or political causal sources.

One might ask what bearing this logic has on contemporary famine cases. One of the main points of the HASAS model is to structure the chain of causality, thereby providing a map of the potential causal sources and directing both research and policy efforts accordingly. The model forces the research to ask, 'What or who may cause scarcity?' and 'How do these factors affect the R-E-A relationship?' For example, generally speaking, the 1998 famine in Bahr al-Ghazal, Sudan, was largely caused by civil war (Deng, 1999), which is similar to previous famines in the region (Keen, 1994) and was conditioned by international interests in the area (Deng, 2002). The military forces of the Sudanese central government intentionally targeted and destroyed agriculture resources in Southern Sudan to gain a strategic military advantage. These forces not only wanted to starve the rebels to death but also sought to destroy the Dinka people's way of life and deprive them of their assets. The underlying causes of this famine are rooted in complex political, economic and social processes that date back to at least

\footnotetext{
${ }^{7}$ However, if we strictly follow Osmani's account, E will always mediate and thus be an active mechanism. This would leave us with four possible combinations.
} 
the time of the first presence of British colonialism (Deng, 1999; De Waal, 2005; Flint and De Waal, 2008; Mukerjee, 2010). Considering the total Sudanese system, there seems to have been enough food (no FAD) (Deng, 2002), but because of the direct destruction of endowments in the local Bahr al-Ghazal, people's livelihoods (production entitlements) were adversely affected (local FAD). This example highlights the importance of good governance (Halleröd et al., 2013; Daoud, 2015).

If the Bengal famine could be explained by some FRI factors but mainly by FED factors, then it seems that the Sudanese famine could be explained by local FAD (driven not by climate shocks but by intentional human actions). A situation similar to the Sudanese case occurred in the 1973 Ethiopian Wollo famine. In this case, the endowments were destroyed not by intentional human actions but by drought (Sen, 1981, pp. 111-12), thus generating a local FAD mediated by FED. Similarly, the Ethiopian famine from 1999 to 2000 was triggered by drought (which then contributed to an FAD) and mediated by an FED. Nevertheless, other factors in the complex emergency situation (primarily the war with Eritrea) further conditioned the Ethiopian people's entitlements (Macrae and Zwi, 1994; Hammond and Maxwell, 2002). The Soviet famine of 1947 was in some respects very similar to the Bengal famine, insofar as appropriate government measures could have countervailed a famine: 'had the priorities of the government been different, there might have been no famine' (Ellman, 2000, p. 603). Instead, adverse changes in people's entitlements led to an FED. The famine in Malawi was not attributable to an FAD but instead to a rapid increase in prices (FED). Hence, what the HASAS model suggests is that researchers need to focus both on the R-E-A relationship and on investigating its underlying causes. A large portion of the analysis should be devoted to human actions and interactions in addition to climate shocks (Archer, 1995; Devereux, 2007; Daoud et al., 2015; Daoud et al., 2016).

What these examples show is that the synthetized approach developed in this paper can potentially be applied to different cases. Although the current approach limits the number of direct causes at seven, it simultaneously allows for numerous indirect causes. One of the main benefits to be gained from this approach is that it organizes the causal links in a more coherent manner.

Moreover, there are several indirect mechanisms that have not been discussed in the current paper but that are important for their effects on R-E-A. What are the roles of improved infrastructure, early warning systems, population control, poverty reduction (technical solutions), democratization, accountability and the development of 'social contracts' between governments and their populations (good governance)? Although the paper does mention some of these factors (for example 'ineffectively coordinated government actions' or the British government's lack of interest in 'providing aid'), the core of the discussion has been around exploring the linkages of he R-E-A relationships, leaving many of the above (important and less narrowly technical) dimensions for future research.

\subsection{FRI as its own ontological dimension}

As suggested by the HASAS model, the situation of famine accountability and response are linked not only to the evasion of FAD and FED but also to FRI (cf. von Braun et al., 1999, pp. 52ff.; Nandy et al., 2016). Considerations of FRI factors seem to be somewhat implicit or even missing.

FRI should be given an explicitly and relatively autonomous ontological status. For example, explicit consideration of FRI factors seems to be missing from the concept of 
food security used by major organizations (see the Food and Agriculture Organisation and the Food Insecurity and Vulnerability Information and Mapping Systems) (Shaw, 2007, pp. 383ff.). According to the FAO, the definition of food security consists of four dimensions, i.e., availability, access, utilization (food preparation) and stability (FAO, 2008). This can be compared to the three causal sources of the HASAS model, specifically, requirements, entitlements and available quantities (R-E-A). Only two of three causal sources are covered. As argued in the paper, a society's increased aggregate food requirements affect individual food security in a fundamental way (FRI). It is true that the empirical measurements of FAD and FRI are effectively equal on a per capita basis (the ratio between food needs and food production), but the underlying ontological causes are very different in each case. Therefore, policy recommendations should be based on this understanding. If food requirements were to increase because of a rapid increase in population, one would recommend a different set of policy measurements (e.g. family planning) than if food availability were declining because of drought (e.g. aid or technological development). Thus, the actual underlying causes of either a famine or food insecurity are central to the type of policy measurement that should be recommended. All three causal sources and the seven possible combinations between them, not merely food availability and food access, are needed to assemble effective policy measures.

\subsection{Some policy considerations}

What theoretical and policy lessons can be learned by comparing different scarcity cases? There are surely many interesting hypotheses to test. One hypothesis, for example, is that social groups that tend to have higher food insecurity also tend to have higher water insecurity. If this is the case, one probable explanation is that they are not entitled to enough water resources (water entitlement decline, WED) even if there is enough water in the system (no water availability decline, WAD), and even if the aggregate demand has increased somewhat (water requirement increase, WRI). A more general hypothesis is that the same social groups that are vulnerable to food insecurity are usually vulnerable to socioeconomic exclusion from accessing basic resources in society (resource entitlement decline, RED), even if there are enough resources on a systemic level (absence of resource availability decline, RAD). This is indeed the definition of poverty, and it calls for an approach that focuses on livelihood security (Dasgupta, 2000; Young and Maxwell, 2009; Coates et al., 2010; Jaspars and O'Callaghan, 2010). Furthermore, in light of the role of speculation in the local and global food markets, which is another important issue, policy and various neoliberal interventions influence the R-E-A relationship. More research is certainly needed on these issues.

At the core of these types of scarcities often lie some type of failure of human action (policy, institutional), unintended consequences (trade-offs between different priorities) or intended human action (war, siege, sanctions), which have been called priority regimes (Howe, 2007). As Keen argues, one must ask questions about the power relations that cause famine: 'what use is famine, what functions does it assure, in what strategies is it integrated?' (Keen, 1994, p. 12). For this reason, policymakers should focus on how their actions affect the R-E-A relationship (that might lead to FAD, FED or FRI), as shown in the case of Bengal. Human action or inaction always underlies scarcity (Drèze and Sen, 1989, p. 47). 
This in turn calls for an intellectual progression: "“from old famine" to "new famine" thinking requires two paradigm shifts: from famines as failures of food availability, to failures of access to food, to failures of accountability and response' (Devereux, 2007 , p. 9). This involves thinking about humanitarian projects and how they fit into a wider global social and political climate (Minear and Smith, 2007).

\subsection{Similarities to other cases of scarcities (food, water, land)}

Another area of interest to which the HASAS model seems to lend itself is not only the comparative study of famine but also other types of scarcity situations (e.g. water, land, fisheries) (cf. von Braun et al., 1999). The basic question is how different causal factors affect the R-E-A relationship in each case and what lessons can be learned from such comparison. As set forth in Table 4, each causal source in the R-E-A relationship has underlying causal factors. The entitlements of individuals or groups of people are conditioned by numerous factors (e.g. class, gender, ethnicity, social policy), which could then be compared over a given number of famines or similar cases. In the case of the Bengal famine, some of the central causal factors that affected entitlements were changes in individual social position (rural or urban) relative to working opportunities (due to the war economy) and the government's social policy (schemes). From a realist perspective (Lawson, 2012), the concept of social positions is one of the central analytical tools with which to understand resource and power differences. In the formation of these positions, a network of emergent organization emerges, which also bears on who can deploy certain entitlements to access given resources in the family, the neighbourhood or the region. Available quantities of food or similar (A factors) are conditioned by, most notably, arable land, technology, policy and the ownership of capital. Requirements for food or similar (R-factors) are conditioned by, for example, demographic changes, social norms, education and family policy (cf. Basu and Amin, 2000;

Table 4. Sketch of a matrix of comparison

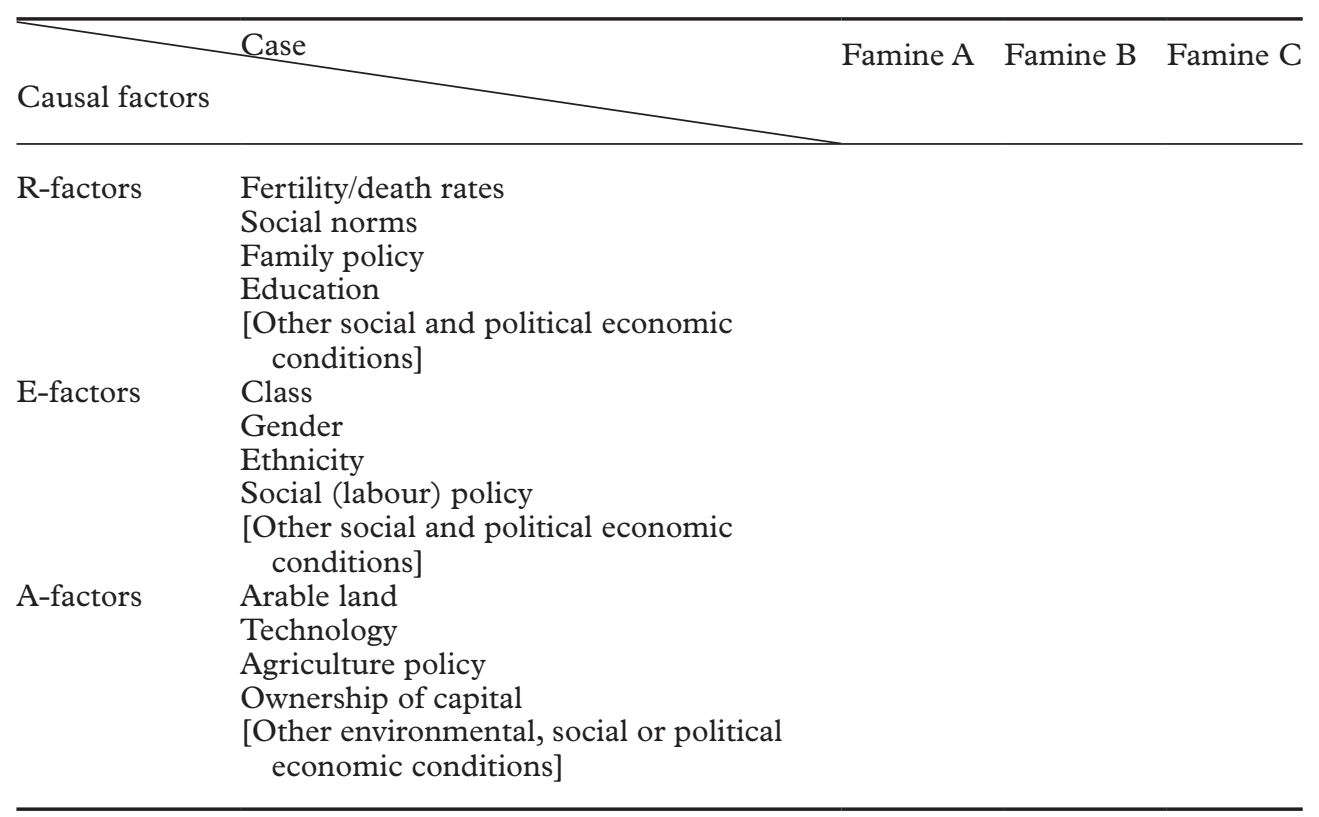


Connelly, 2006; Daoud and Puaca, 2011; Puaca and Daoud, 2011). Of course, the qualitative character of each scarcity case specifies the underlying causal factors, as set forth in Table 4 .

The HASAS model is presented as a general approach to scarcity events, famine being only one such event. Another research implication or suggestion is to investigate the link between food (security) scarcity and other types of scarcities (e.g. water, land, housing, energy, education, and healthcare). For example, water scarcity is a growing global problem (Brown, 2009). It causes poor sanitation and health problems, and water is, of course, crucial to food production. Similar to famine, different segments of the population have different levels of water security. Thus, an interesting research project would be to investigate the link between food and water scarcity, as structured by the HASAS model. One commonly studied causal link is the question of how water scarcity affects food scarcity in terms of both agriculture and basic sanitation (De Waal, 2005); however, another, less studied link is the question of the similarities and differences between water and food scarcity as such, as cases of scarcity.

Accordingly, and to conclude this paper, the HASAS model provides a framework in which central insights into FAD, FED and FRI can be used simultaneously. This is one of the strengths of the HASAS model, specifically, that it bridges the ontological gap between opposing causal approaches. Finally, a multi-causal model calls for interdisciplinary research and encourages a mixed-methods approach (Shaw, 2007, p. 383). That said, the HASAS model suggests that various scarcity cases (famines, poverty, water scarcity, land scarcity and the like) can be understood through a similar framework, but conditioned by a plurality of causes. More research is indeed required to reveal new causal links.

\section{Bibliography}

Alamgir, M. 1980. Famine in South Asia: Political Economy and Mass Starvation, Cambridge, MA, Oelgeschlager, Gunn \& Hain

Alemu, G. 2007. Revisiting the entitlement approach to famine: taking a closer look at the supply factor-a critical survey of the literature, Eastern Africa Social Science Research Review, vol. 23, no. 2, 95-129

Allen, G. 1983. The value of Sen's poverty and famines, Food Policy, vol. 8, no. 4, 347-48

Allen, G. 1986. Famines: the Bowbrick-Sen dispute and some related issues, Food Policy, vol. 11 , no. 3, 259-63

Archer, M. S. 1995. Realist Social Theory: The Morphogenetic Approach, Cambridge, Cambridge University Press

Baert, P. 1996. Realist philosophy of the social sciences and economics: a critique, Cambridge Fournal of Economics, vol. 20, no. 5, 513-22

Basu, A. M. and Amin, S. 2000. Conditioning factors for fertility decline in Bengal: history, language identity, and openness to innovations, Population and Development Review, vol. 26, no. 4, 761-94

Basu, D. R. 1984. Food policy and the analysis of famine, Indian fournal of Economics, vol. 64, no. 254, 289-301

Basu, D. R. 1986. Sen's analysis of famine: a critique, fournal of Development Studies, vol. 22, no. 3, 598-603

Bhatia, B. M. 1967. Famines in India: A Study in Some Aspects of the Economic History of India (1860-1965), London, Asia Publishing House

Bhrolcháin, M. N. and Dyson, T. 2007. On causation in demography: issues and illustrations, Population and Development Review, vol. 33, no. 1, 1-36

Blankenburg, S., Lawson, C., Lawson, T., Lewis, P., Pratten, S., and Runde, J., 2002. Introduction. Cambridge fournal of Economics, vol. 26, 679-81 


\section{Synthesizing the Malthusian and Senian approaches}

Bose, S. 1990. Starvation amidst plenty: the making of famine in Bengal, Honan and Tonkin, 1942-45, Modern Asian Studies, vol. 24, no. 4, 699-727

Bowbrick, P. 1986. The causes of famine: a refutation of Professor Sen's theory, Food Policy, vol. 11, no. 2, 105-24

Bowbrick, P. 1987. Rejoinder: an untenable hypothesis on the causes of famine, Food Policy, vol. 12 , no. $1,5-9$

Brown, A., Slater, G., and Spencer, D. A. 2002. Driven to abstraction? Critical realism and the search for the 'inner connection' of social phenomena, Cambridge fournal of Economics, vol. 26 , no. 6, 773-88

Brown, L. 2009. Plan B 4. 0: Mobilizing to Save Civilization, New York, W. W. Norton \& Company Castellacci, F. 2006. A critical realist interpretation of evolutionary growth theorising, Cambridge Fournal of Economics, vol. 30, no. 6, 861-80

Coates, J., Maxwell, D., Tadesse, G., Hailu, S., Zeweld Nugussie, W., and Gebrekiros, A. 2010. Institutional Assessment Report: Tsaeda Amba Woreda, Eastern Tigray, Ethiopia-Research Program on Livelihood Change Over Time, Medford, Feinstein International Center, Tufts University

Connelly, M. 2006. Population control in India: prologue to the emergency period, Population and Development Review, vol. 32, no. 4, 629-67

da Graca Moura, M. and Martins, N. 2008. On some criticisms of critical realism in economics, Cambridge fournal of Economics, vol. 32, no. 2, 203-18

Daoud, A. 2007. (Quasi)scarcity and global hunger: a sociological critique of the scarcity postulate with an effort to synthesis, Fournal of Critical Realism, vol. 6, no. 2, 199-225

Daoud, A. 2010. Robbins and Malthus on scarcity, abundance, and sufficiency, American fournal of Economics and Sociology, vol. 69, no. 4, 1206-29

Daoud, A. 2011 a. Scarcity, Abundance, and Sufficiency: Contributions to Social and Economic Theory, Gothenburg Studies in Sociology. Gothenburg Studies in Sociology, Gothenburg, Department of Sociology

Daoud, A. $2011 \mathrm{~b}$. The modus vivendi of material simplicity: counteracting scarcity via the deflation of wants, Review of Social Economy, vol. 69, no. 3, 275-305

Daoud, A. 2015. Quality of governance, corruption and absolute child poverty in India, fournal of South Asian Development, vol. 10, no. 2, 148-67

Daoud, A., Halleröd, B., and Guha-Sapir, D. 2015. 'Reoccurring Natural Disasters, Quality of Government, and Severe Child Deprivation-A Comparative Analysis of 67 Developing Countries', Max Planck Institute for the Studies of Societies Working Paper Series

Daoud, A., Halleröd, B., and Guha-Sapir, D. 2016. What is the association between absolute child poverty, poor governance, and natural disasters? A global comparison of some of the realities of climate change, PLOS ONE, vol. 11 , no. 4, e0153296

Daoud, A. and Puaca, G. 2011. An organic view of want formation: pragmatic rationality, habitus and reflexivity, British fournal of Sociology of Education, vol. 32, no. 4, 603-22

Dasgupta, P. 2000. Population and resources: an exploration of reproductive and environmental externalities, Population and Development Review, vol. 26, no. 4, 643-89

Davis, J. B. 2008. The turn in recent economics and return of orthodoxy, Cambridge fournal of Economics, vol. 32, no. 3, 349-66

De Waal, A. 1990. A re-assessment of entitlement theory in the light of the recent famines in Africa, Development \& Change, vol. 21, no. 3, 469-90

De Waal, A. 2005. Famine That Kills: Darfur, Sudan, New York, Oxford University Press

Deng, L. 1999. Famine in the, Sudan: causes, preparedness and response. A political, social and economic analysis of the 1998 Bahr El Ghazal famine, IDS Discussion Paper 369

Deng, L. B. 2002. The Sudan famine of 1998: unfolding of the global dimension, IDS Bulletin, vol. 33, no. 4, 28-38

Devereux, S. 1988. Entitlements, availability and famine: a revisionist view ofWollo, 1972-1974, Food Policy, vol. 13, no. 3, 270-82

Devereux, S. 2007. The New Famines: Why Famines Persist in an Era of Globalization, London, Routledge

Dow, A. C. and Dow, S. C. 2005. The application of development economics: general principles and context specificity, Cambridge fournal of Economics vol. 29, no. 6, 1129-43

Downward, P. 2000. A realist appraisal of post-Keynesian pricing theory, Cambridge fournal of Economics, vol. 24, no. 2, 211-24 
Downward, P., Finch, J. H., and Ramsay, J. 2002. Critical realism, empirical methods and inference: a critical discussion, Cambridge fournal of Economics, vol. 26, no. 4, 481-500

Drèze, J. and Sen, A. K. 1989. Hunger and Public Action, Oxford, Clarendon and Publishing House

Dyson, T. and Maharatna, A. 1991. Excess mortality during the Bengal famine: a re-evaluation, Indian Economic \&o Social History Review, vol. 28, no. 3, 281-97

Ellman, M. 2000. The 1947 Soviet famine and the entitlement approach to famines, Cambridge Fournal of Economics, vol. 24, no. 5, 603-30

Famine Inquiry Commission. 1945. Report on Bengal, New Delhi, Government of India

FAO. 2008. An introduction to the basic concepts of food security, Rome, EC-FAO Food Security Programme

Fine, B. 1997. Entitlement failure?, Development and Change, vol. 28, no. 4, 617-47

Fleetwood, S. 1996. Order without equilibrium: a critical realist interpretation of Hayek's notion of spontaneous order, Cambridge fournal of Economics, vol. 20, no. 6, 729-47

Fleetwood, S. (ed.). 1999. Critical Realism in Economics: Development and Debate, Economics as Social Theory, London, Routledge

Flint, J. and De Waal, A. 2008. Darfur: A New History of a Long War, London, Zed Books

Gasper, D. 1993. Entitlements analysis: relating concepts and contexts, Development and Change, vol. 24 , no. $4,679-718$

Goswami, O. 1990. The Bengal famine of 1943: re-examining the data, Indian Economic E Social History Review, vol. 27, no. 4, 445-63

Greenough, P. R. 1982. Prosperity and Misery in Modern Bengal: The Famine of 1943-1944, New York, Oxford University Press

Halleröd, B., Rothstein, B., Daoud, A., and Nandy, S. 2013. Bad governance and poor children: a comparative analysis of government efficiency and severe child deprivation in 68 low- and middle-income countries, World Development, vol. 48, 19-31

Hammond, L. and Maxwell, D. 2002. The Ethiopian crisis of 1999-2000: lessons learned, questions unanswered, Disasters, vol. 26, no. 3, 262-79

Hodge, D. 2008. Economics, realism and reality: a comparison of Maki and Lawson, Cambridge Fournal of Economics, vol. 32, no. 2, 163-202

Howe, P. 2007. Priority regimes and famine, p. 367 in Devereux, S. (ed.), The New Famines:Why Famines Persist in an Era of Globalization, New York, Routledge

Islam, M. M. 2007. The great Bengal famine and the question of fad yet again, Modern Asian Studies, vol. 41, no. 2, 421-40

Jackson, W. A. 2005. Capabilities, culture and social structure, Review of Social Economy, vol. 63, no. $1,101-24$

Jaspars, S. and O'Callaghan, S. 2010. Challenging Choices: Protection and Livelihoods in Conflict Case Studies from Darfur, Chechnya, Sri Lanka and the Occupied Palestinian Territories, London, Humanitarian Policy Group and Overseas Development Institute

Kaul, N. 2002. A critical 'post' to critical realism, Cambridge fournal of Economics, vol. 26, no. 6, 709-26

Keen, D. 1994. The Benefits of Famine: A Political Economy of Famine and Relief in Southwestern Sudan, 1983-9, Princeton, NJ, Princeton University Press

Kula, E. 1989. Politics, economics, agriculture and famines: the Chinese case, Food Policy, vol. 14 , no. $1,13-16$

Law-Smith, A. 1989. Response and responsibility: the government of India's role in the Bengal famine, 1943, South Asia: Fournal of South Asian Studies, vol. 12, no. 1, 49-65

Lawson, T. 1997. Economics and Reality, London, Routledge

Lawson, T. 2006. The nature of heterodox economics, Cambridge fournal of Economics, vol. 30, no. $4,483-505$

Lawson, T. 2012. Ontology and the study of social reality: emergence, organisation, community, power, social relations, corporations, artefacts and money, Cambridge fournal of Economics, vol. $36,345-85$

Lee, F. S. 2002. Theory creation and the methodological foundation of post Keynesian economics, Cambridge fournal of Economics, vol. 26, no. 6, 789-804

Lee, J. and Feng, W. 1999. Malthusian models and Chinese realities: the Chinese demographic system 1700-2000, Population and Development Review, vol. 25, no. 1, 33-65 
Macrae, J. and Zwi, A. B. 1994. War and Hunger: Rethinking International Responses to Complex Emergencies, London, Zed Books

Mallory, W. H., Vinacke, H. M., and King-Hall, S. 1926. China: Land of Famine, New York, American Geographical Society

Malthus, T. R. 1826. An Essay on the Principle of Population, or a View of Its Past and Present Effects on Human Happiness; with an Inquiry into Our Prospects Respecting the Future Removal or Mitigation of the Evils Which It Occasions, London, John Murray

Mansergh, N. and Lumby, E. W. R. 1973. The Transfer of Power 1942-47, Vol. 4, the Bengal Famine and the New Viceroyalty, 15 fune 1943-31 August 1944, London, H.M.S.O.

Martins, N. 2006. Capabilities as causal powers, Cambridge fournal of Economics, vol. 30, no. 5, 671-85

Martins, N. 2007. Ethics, ontology and capabilities, Review of Political Economy, vol. 19, no. 1, 37-53

Martins, N. 2013. The Cambridge Revival of Political Economy, London, Routledge

Marx, K. 1853. The British rule in India, New-York Daily Tribune, 25 June

Minear, L. and Smith, H. (eds.). 2007. Humanitarian Diplomacy: Practitioners and Their Craft, Tokyo, United Nations University Press

Moon, P. (ed.). 1973. Wavell: The Viceroy's fournal, London, Oxford University Press

Mukerjee, M. 2010. Churchill's Secret War: The British Empire and the Ravaging of India during World War II, New York, Basic Books

Nandy, S., Daoud, A., and Gordon, D. 2016. Examining the changing profile of undernutrition in the context of food price rises and greater inequality, Social Science and Medicine, vol. 149, 153-63

Nielsen, P. 2002. Reflections on critical realism in political economy, Cambridge fournal of Economics, vol. 26, no. 6, 727-38

Ó Gráda, C. 2008. The ripple that drowns? Twentieth-century famines in China and India as economic history, Economic History Review, vol. 61, no. 1, 5-37

Osmani, S. 1995. The entitlement approach to famine: an assessment, in Basu, K., Pattanaik, P., and Suzumura, K. (eds.), Choice, Welfare and Development: A Festschrift in Honour of Amartya K. Sen, Oxford, Clarendon Press

Padmanahan, S. Y. 1973. The great Bengal famine, Annual Review of Phytopathology, vol. 11, no. $1,11-24$

Patnaik, U. 1991. Food availability and famine: a longer view, fournal of Peasant Studies, vol. 19, no. $1,1-25$

Peacock, M. 2008. Transforming economics into what? Heterodox economics and critical realism, Cambridge fournal of Economics, vol. 32, no. 2, 219-33

Peter, F. 2001. Rhetoric vs realism in economic methodology: a critical assessment of recent contributions, Cambridge fournal of Economics, vol. 25, no. 5, 571-89

Poulton, C., Kydd, J., Wiggins, S., and Dorward, A. 2006. State intervention for food price stabilisation in Africa: can it work?, Food Policy, vol. 31, no. 4, 342-56

Puaca, G. and Daoud, A. 2011. Vilja och framtid i frågor kring utbildningsval, Pedagogisk Forskning, vol. 16, no. 2, 100-117

Qudrat-I Elahi, K. 2006. Entitlement failure and deprivation: a critique of Sen's famine philosophy, Fournal of Development Studies, vol. 42, no. 4, 541-58

Rangasami, A. 1985. Failure of exchange entitlements' theory of famine: a response, Economic and Political Weekly, vol. 20, no. 41, 1747-52

Ravallion, M. 1987. Markets and Famines, Clarendon, Oxford

Robinson, A. 1974. The economic development of Malthusia, Modern Asian Studies, vol. 8, no. 4, 521-34

Rubin, O. 2009. The Niger famine: a collapse of entitlements and democratic responsiveness, Fournal of Asian and African Studies, vol. 44, no. 3, 279-98

Sen, A. 1986. The causes of famine: a reply, Food Policy, vol. 11, no. 2, 125-32

Sen, A. 1987. Reply: famine and Mr Bowbrick, Food Policy, vol. 12, no. 1, 10-14

Sen, A. 1993. The causation and prevention of famines: a reply, fournal of Peasant Studies, vol. 21 , no. $1,29-40$

Sen, A. K. 1977. Starvation and exchange entitlements: a general approach and its application to the great Bengal famine, Cambridge fournal of Economics, vol. 1, no. 1, 33-59 
Sen, A. K. 1981. Poverty and Famines: An Essay on Entitlement and Deprivation, Oxford, Clarendon and Publishing House

Shaw, J. D. 2007. World Food Security: A History Since 1945, Basingstoke, Palgrave Macmillan

Smith, M. L. and Seward, C. 2009. The relational ontology of Amartya Sen's capability approach: incorporating social and individual causes, Fournal of Human Development and Capabilities, vol. 10, no. 2, 213-35

Tauger, M. B. 2003. Entitlement, shortage and the 1943 Bengal famine: another look, fournal of Peasant Studies, vol. 31, no. 1, 45-72

Tauger, M. B. 2009. The Indian famine crises of World War II, British Scholar fournal, vol. 1, no. $2,166-96$

von Braun, J., Tesfaye, T., and Webb, P. 1999. Famine in Africa: Causes, Responses, and Prevention, Baltimore, Johns Hopkins University Press for the International Food Policy Research Institute

Wheatcroft, S. G. 2007. On continuing to misunderstand arguments: response to Mark Tauger, Europe-Asia Studies, vol. 59, no. 5, 847-68

Wrigley, E. A. 1999. Corn and crisis: Malthus on the high price of provisions, Population and Development Review, vol. 25, no. 1, 121-28

Young, H. and Maxwell, D. 2009. Targeting in Complex Emergencies: Darfur Case Study, Medford, MA, Medford Feinstein International Center, Tufts University 